\title{
Recognition of Taxes and Implementation of Tax Procedures by SMEs in Albania
}

\author{
Etleva Bajrami
}

\begin{abstract}
In Albania, most businesses are classified as SMEs and their importance in the economy has grown exponentially in recent years. As SMEs comprise the majority of businesses, their taxes are crucial for the state budget. The purpose of this paper is to understand the SMEs' attitude toward tax compliance. The objective of this research is to assess tax knowledge of SMEs as a precondition for tax compliance. Tax noncompliance has been a prevalent issue, and the tax authorities have undertaken a reform in this regard. This paper aims to understand the current situation regarding tax compliance. The current study is based on questionnaires distributed to 348 SMEs. Businesses responded to questions related to the recognition of taxes, duties and procedures. SMEs are separated in two groups, small and medium by annual turnover, in order to achieve the most accurate survey results. The results of the questions were not always the same for both groups. There are more small businesses that are not familiar with taxes, duties and tax procedures, resulting in conclusion that medium businesses are more tax compliant than small businesses. Tax authorities need to know the situation of SMEs, get their opinions on taxes and duties and take them into consideration.
\end{abstract}

KEY WORDS: $\quad$ SME, compliance, taxes, Albania.

JEL Classification: H26, E62, H32.

Finance Department, Faculty of Economy, Tirana University, Albania

\section{Introduction}

Tax compliance is very important for the state budget. Budget spending has been increasing over the years. A higher standard of living has led the public administration to put constant pressure on salary growth, increasing public demand for better services, modern infrastructure, public debt repayment, and so forth. This requires full collection of taxes and duties.

The tax administration should be careful in collecting taxes and duties so that all taxpayers are treated equally. This equality is important to ensure fair and honest competition. A business which does not pay its duties would be more competitive in the

Correspondence concerning this article should be addressed to: Etleva Bajrami, Faculty of Economy, Tirana University. Arben Broci, Tirane, Albania

E-mail: etlevabajrami@feut.edu.al market than its competitors. That is because such a business would have more funds for renovations, studies, research, or even discounts and other offers aimed at customers, thus enabling growth in their market share by attracting new customers from their direct competitors.

If tax inspectors find taxpayers defaulting on their tax obligations, they will apply high penalties and this will cause financial problems for business activity. According to Agu et al. (2015) public expenditure on economic services strongly affects economic stability and growth. Public spending contributes positively to the growth of private sector. Tax noncompliance will cause fewer revenues in the state budget and this will have many effects in the economy. The consequences in businesses activities are not easy to calculate if the infrastructure is not appropriate. The lack of investments in roads and ports 
will cause delays or government services will cause time-consuming costs due to staff shortages that are due to missing budget revenue.

Exact calculation of taxes and duties enables businesses to understand the real situation in which they are operated, enabling timely response in case of a bad performance, during the economic fluctuations and competition movements.

The current paper focuses on SMEs - they are the largest share of businesses in Albania and conduct most of the investments. SMEs have the highest number of employees in total and as consequence, their tax compliance is crucial. It is very important for these businesses to declare the correct number of employees in order to pay personal income tax and social and health contributions accurately.

Social and health contributions are compulsory for employed persons, the self-employed and employers. At present, the Social Insurance Institute has difficulty in covering current pensions. The low level of pensions remains a problem in Albania. The state budget meets the needs for funds of the Social Insurance Institute. From the data of Ministry of Finance and Economy (2018) is calculated that Social Insurance Institute incomes account for $16 \%$ of total state budget revenue, while expenditures account for about $26 \%$ of annual budget expenditures. Correct payment of contributions would help in this regard.

The employees themselves agree to not declare the gross salary in order to reduce the contribution payment. They are not taking into account the costs they will have when they themselves will be part of the third age, and will benefit an inadequate pension for a normal lifestyle. On the other hand businesses do not take into account the fact that pensioners are part of their potential and real customers.

Declaring the number of employees and their real wages was one of the objectives of the recent tax reform. All subjects want public goods and services, without which they cannot perform their activities. Public goods and services are not directly linked to the amount of tax the taxpayers pay, which creates the desire and the opportunity not to pay tax liabilities.

It is very important for taxpayers to know which taxes and duties, and at what levels, apply to them. It is necessary for businesses to understand that tax noncompliance implies a loss of revenues which are essential for the state budget. This loss of revenues will cause a distribution of government goods and services based on budget opportunities, which will imply economic effects. As previously mentioned, nonpayment of duties also damages the market economy because it provides competitive advantages for those who do not pay.

Tax administration rules and procedures aim to clarify and to ensure the correct implementation of the law, to ensure tax administration at a lower cost, both for the tax administration and the taxpayer. It is essential that the tax administration authorities understand the SMEs business way, in order to understand whether they comply with taxes or not. This study tries to find out if SMEs recognize their taxes, duties, and procedures to decide about tax compliance. According to the Doing Business report both the number of payments and the time spent making payments in Albania are higher than in Europe and Central Asia (World Bank, 2018a).

The current paper is an attempt at filling the gap in the study of tax compliance in Albania, and especially for tax recognition. This study will help tax authorities for administration and decision making in tax legislation through understanding the problem of tax non-compliance by SMEs. This study also helps businesses understand their situation and raise their awareness of paying taxes and duties correctly.

This paper is organized in two parts. The first part introduces the importance of SMEs and their tax compliance through the literature review, their development and role in the domestic economy. The second part presents the research conducted through the questionnaires addressed to SMEs to understand the recognition of taxes, duties and tax procedures.

\section{Literature Review}

Small and medium businesses are considered a high risk group of tax compliance. According to OECD (2004) revenue authorities should continually check tax compliance of taxpayers. It is the role of the revenue authorities to identify problematic entities with tax evasion issues, like noncompliance with the obligations or inconsistency payment of duties. Revenue authorities should identify 
as well as cases when taxpayers are not licensed. However, the level of tax rates must be acceptable to all taxpayers. The cost of starting up a company, of registering a company, the time spends on tax administration and enforcing contract procedures seems to be important and have negative impact in SME growth. The main goal for the vast majority of EU member states remains to reduce bureaucracy to improve the SME regulatory environment (Aristovnik \& Obadić, 2015).

The problem of non-compliance is an international problem. Three of the main factors affecting taxpayer non-compliance are the rate structure, tax complexity, and control system. Because non-compliance causes a significant difference between paid tax liabilities and tax liabilities to be paid in real terms, it should be given special attention (Strader \& Fogliasso, 1989).

According to Ravšelj and Aristovnik (2018), regulatory authorities should consider the characteristics of small businesses and how they deal with administrative barriers when preparing and developing the legislation. This is because different SME groups use different ways of overcoming administrative barriers in the area of tax compliance. Small businesses have insufficient financial resources to pay for external accounting services and limited staff.

SMEs decide to file and pay their taxes incorrectly for a number of reasons, but most important is the high level of tax and duty rates (Atawodi \& Ojeka, 2012).It is the finance manager or tax manager who calculates the tax expense and decides on the preferred level of taxation or the preferred level of tax avoidance without taking into account the consequences in the future (Waegenaere et al., 2015).

Umar et al. (2017) in their research sought to understand the motivations behind noncompliance in developing countries. They found the existence of an extensive tax boycott from taxpayers. Taxpayers justified their position because of harsh socioeconomic living condition, disengagement from governance, and dysfunctional audit system. Economists for many reasons find it difficult to count the total tax burden. The total tax burden consists of several components, one of which is compliance cost, the cost of conforming to often complex and changing tax laws (Bohanon et al., 2014).

According to Abotsi et al. (2014), for small and medium businesses government policies and taxes influence negatively risk manage $\neg$ ment decision making by managers because the tax competes with the cost of risk management and other business expenditures. Ropret et al. (2018) in their research concluded that new small businesses lack the knowledge of regulatory requirements and frequent changes in administrative procedures affect the performance of businesses. Consequently, removing administrative barriers will have a direct impact on the business environment by improving it. A clear guide should be created for responsible policy makers to remove administrative barriers for promoting growth of small business.

For businesses, tax obligations are as important as it is the procedure of giving tax coupons or tax receipts to customers in every purchase. Since the categorization of businesses is based on annual turnover in Albania, it is important that businesses give tax coupons at every sale for confirming the sale. Giving and registering tax coupons will also help the business understand its performance in the market compared to competitors. Annual turnover is determined on the basis of tax coupons. This also helps businesses make financial statements. According to Oliver (2015) the financial statements of a business should be as accurate as possible. This is because for business is of a great importance financial transparency, assessment of tax liabilities, better decision making, planning and financial forecasting, etc.

A recent report by World Bank Group (2018b) stresses the importance of technology for the accurate payment of taxes, as technologically advanced states have higher tax compliance. This is especially important for businesses that have many registrations and therefore technology would speed up the process of paying and filing tax declarations. Tax authority in Albania will undertake another reform consisted in advanced technology.

Taxpayers are affected by the public goods and services they benefit. So, if a taxpayer is more confident regarding the public services offered, 
they will be more willing to pay. Also taxpayers will increase their compliance if they overestimate tax controls and potential penalties (Alm et al., 1992). According to Frey (2011) punishment is not able to reduce crime and that punishment involves good and bad and loses both. If people are aware that society as a whole is correct to law, then each of them will have a correct attitude to the law.

Noncompliance of taxpayers is explained by taxpayers' attitude towards the tax system and the way tax agents treat the taxpayer. Also, if taxpayers think that the tax burden is not fair this will negatively affect their attitude towards paying taxes (Bărbuță-Mişu, 2011).From the research conducted from Virglerová et al. (2016) at SMEs in the Czech Republic, according to the responses of entrepreneurs, the state helps in their entrepreneurship. It is also found that corruption and clientelism poses a major problem for the country's enterprises, the longer they are in the market the more they encounter corruption and clientelism.

According to Nyamwanza et al.(2014), most SMEs were found not to comply with income tax and PAYE, stating lack of confidence in the tax system. The process of complying is considered as costly - from both time and financial perspective.

According to Doran (2009) tax compliance is determined by tax fines. Tax compliant taxpayers and non-compliant taxpayers are determined through tax penalties. The self-declaration system means that the state puts trust in taxpayers filing their tax declarations correctly. In Albania, taxpayers operate through self-declaration. Businesses make assessments of taxes they have to pay, then declare and pay the amount assessed.

\section{General Economic and SMEs' Performance}

The growth rate of the economy in Albania has had its own fluctuations. The economic growth can be deemed satisfactory, until 2008. Although after 2008 the growth rate fell, in the last 3 years the growth rates of the economy have been positive.

The importance of SMEs in Albania is indisputable. In 2016, SMEs accounted for about $99.9 \%$ of all ac- tive enterprises. SMEs are the largest number of active companies and consequently the activity they develop in the economy is the largest share of net sales about $77.8 \%$ of all. Investments by the SMEs in the economy are significant, comprising $74.9 \%$ of all investments. These businesses are highly important in the employment market, employing $81 \%$ of all employees (INSTAT, 2018a).

Figure 1 shows the performance of the total collection of taxes and social and health insurance contributions as well as the collection graphs of taxes and social security contributions collected separately. The data for 2018 are predicted. As it seems, the overall income chart looks similar to the tax collection chart, which is expected as tax revenue accounts for about 80 $\%$ of the budget revenue.

In recent years, Albania has experienced a surge in emigration rates, especially among younger people. At the same time, the number of births has decreased for many reasons, such as life style changes and families' economic issues. These reasons will lead to a fast aging of the population and increasing the care needs of the elderly (INSTAT, 2014). This will increase the need for higher revenues in the Social Insurance and Health Care Institutes. Since emigration has reduced the young labor force, then it will need an increased coverage from the state budget for retirement spending.

The rates of social and health insurance contributions have been stable for years while the related procedures have changed. The health insurance rate applies to all gross wages, while the social security rate applies to the payroll limits. The payroll limits have grown steadily and the upper limit or maximum wage is almost double the average salary. The increase of the maximum wage on which the social contributions rate is applied has led to increased revenues in the state budget from this duty. From the Table 2, is seen that however the social security incomes are well below social security expenses.

The increase of the average salary has contributed to the increase of the state budget revenues. The unemployment rate has decreased in the last 3 years. This trend has continued in 2018, so in the second quarter of 2018, the official unemployment rate in Albania for the population aged 15 and over is $12.4 \%$ (INSTAT, 
Table 1. The Growth Rate of GDP

\begin{tabular}{lccccccccccc}
\hline Years & $\mathbf{2 0 0 0}$ & $\mathbf{2 0 0 1}$ & $\mathbf{2 0 0 2}$ & $\mathbf{2 0 0 3}$ & $\mathbf{2 0 0 4}$ & $\mathbf{2 0 0 5}$ & $\mathbf{2 0 0 6}$ & $\mathbf{2 0 0 7}$ & $\mathbf{2 0 0 8}$ & $\mathbf{2 0 0 9}$ & $\mathbf{2 0 1 0}$ \\
\hline Real growth of GDP & 6,95 & 8,29 & 4,54 & 5,53 & 5,51 & 5,53 & 5,90 & 5,98 & 7,5 & 3,35 & 3,71 \\
\hline Years & $\mathbf{2 0 1 1}$ & $\mathbf{2 0 1 2}$ & $\mathbf{2 0 1 3}$ & $\mathbf{2 0 1 4}$ & $\mathbf{2 0 1 5}$ & $\mathbf{2 0 1 6}$ & $\mathbf{2 0 1 7}$ \\
\hline Real growth of GDP & 2,55 & 1,42 & 1,00 & 1,77 & 2,22 & 3,40 & 3,90 \\
\hline
\end{tabular}

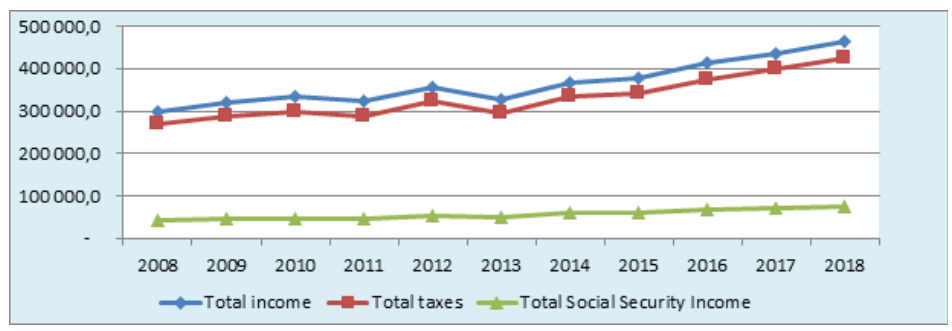

Figure 1. The progress of tax collection and contributions (in million ALL).

Table 2. Total Social Security Income in million ALL

\begin{tabular}{|c|c|c|c|c|c|c|c|c|c|c|c|}
\hline Years & 2008 & 2009 & 2010 & 2011 & 2012 & 2013 & 2014 & 2015 & 2016 & 2017 & 2018 \\
\hline Total Social & 42936,0 & 44322,0 & 46482,0 & 45041,0 & 51577,0 & 51069,0 & 61426,0 & 60148,0 & 66871,0 & 70268,2 & 75155,6 \\
\hline \multicolumn{12}{|l|}{ Security } \\
\hline \multicolumn{12}{|l|}{ Income } \\
\hline Total Social & 66713,0 & 71440,0 & 79419,0 & 79316,0 & 89765,3 & 93984,0 & 101483,0 & 106448,0 & 111479,0 & 117600,0 & 124565,0 \\
\hline \multicolumn{12}{|l|}{ Security } \\
\hline Expense & & & & & & & & & & & \\
\hline
\end{tabular}


$2018 b)$. However, this requires a special study whether this has come as a result of employment or is affected by the emigration of the unemployed in the recent years.

One of the main problems of the state budget recent in years is the non-payment of tax liabilities by taxpayers. In addition to the lack of willingness to pay taxes by taxpayers, high corruption in taxes and customs has been reported. Corruption is reflected in all national and international bulletins, which has a negative impact on the budget. It has also caused low public confidence in the authorities.

The current paper also focuses on local tax revenues called own source revenues for municipality, which enable the municipality to make decisions on how to use the revenues and to ensure self-government. The financial resources of the municipalities have increased on a total level and in particular on their own resources. According to the Status Report on Local Public Finance (Ministry of Finance and Economy, 2019), the ratio of own source revenues to total sources of local budget for Albania is $29.1 \%$ while the average of this report for SEE countries is $34.4 \%$. In terms of whether the planned revenue is achieved, it turns out results that were around $11 \%$ less than the plan, a \% age that varies from one municipality to another. About $61.8 \%$ of total revenue from local taxes is collected in the municipality of Tirana. This is also a reason for conducting this study with questionnaires in Tirana.

In 2015, the General Directorate of Taxation implemented one of the major reforms, the reform against informality. The aim of this reform was to formalize all businesses without exception. First, the goal was to oblige all businesses to be licensed and thus to identify their total number. Another goal was the establishment of fiscal device through which tax coupons would be given to customers. Fiscal device serves to register annual turnover, and through it is possible to identify tax liabilities. The main goal of this reform was that, through the necessary mechanisms of tax procedures to increase revenues in the state budget and local state budget.

To achieve these goals and to result in a successful campaign, the General Directorate of Taxation has taken a series of measures such meetings with interest groups for informing taxpayers about legal changes, increasing awareness of public for receiving the fiscal coupon, advertising campaign against informality through media, etc. (General Tax Directorate, 2015).

\section{Data and Methodology}

The methodology used in this paper was chosen according to its goal, which is to understand the SMEs attitude toward tax compliance. The data for the research was collected using questionnaires. The data for the research was collected using questionnaires which were pilot tested on SMEs randomly selected in the city of Tirana. The questionnaire was given to be completed by them after the verification of their status as SMEs.

The questionnaires were completed by persons who managed tax payments, issuing coupons and tax receipts, whether they were owners or business financiers. Businesses in Albania are divided into small and medium businesses with annual turnover up to ALL 8 million and in big businesses with annual turnover of more than ALL 8 million. The reason for focusing on SMEs is for their importance in the economy of Albania. The article shows partial results of the research conducted at SMEs. The questions are designed to achieve the objective and purpose of this paper.

Between November 2017 and February 2018, are distributed questionnaires in 348 small and medium businesses in the city of Tirana. This paper has divided businesses into two groups, small and medium businesses in order to address accurately the problems that affect tax compliance and for figuring out which group of businesses is more tax noncompliance. In the first group are included small businesses with an annual turnover of 0 to 5 million. In the second group are included medium businesses with annual turnover ranging from ALL 5 million to 8 million. $13 \%$ of the businesses are medium businesses, $85 \%$ are small businesses, and $2 \%$ of the businesses have not shown annual turnover and are specified as undefined or unspecified businesses.

\section{Findings and Discussion}

The questionnaires were completed by 348 small and medium businesses in total and their grouping into small and medium-sized businesses is presented in Table 3. The answers are divided between small and medium businesses for understanding better the problems in tax compliance and recognition of tax procedures. The questionnaire addressed to businesses has been 
comprehensive with a high number of questions. According to the Albanian tax legislation, businesses with annual turnover ranging from ALL 5 to 8 million (medium) pay an income tax of $5 \%$, called simplified income tax, while businesses with annual turnover over 8 million are defined as big businesses and are subject to income tax or corporate tax, but these last one are not subject of this study. Small businesses don't have to pay any form of income taxes.

In the survey businesses were asked about some main local taxes such as:

- Simplified income tax

- Property tax

- Table Tax

- Education Tax (Temporary Tax)
The businesses are asked also for:

- Social and health insurance contributions

- VAT

Businesses have been asked about the social and health insurance contributions because of the importance for social protection.

Businesses with annual turnover over ALL 2 million are subject to VAT. The businesses are either subject to VAT or are potentially to be taxed with VAT. VAT is a tax where evasion is present, some schemes of VAT hiding have been revealed by tax authorities.

One of the questions was about the obligations the businesses were actually aware of. Businesses choose between alternatives provided. Alternatives repre-

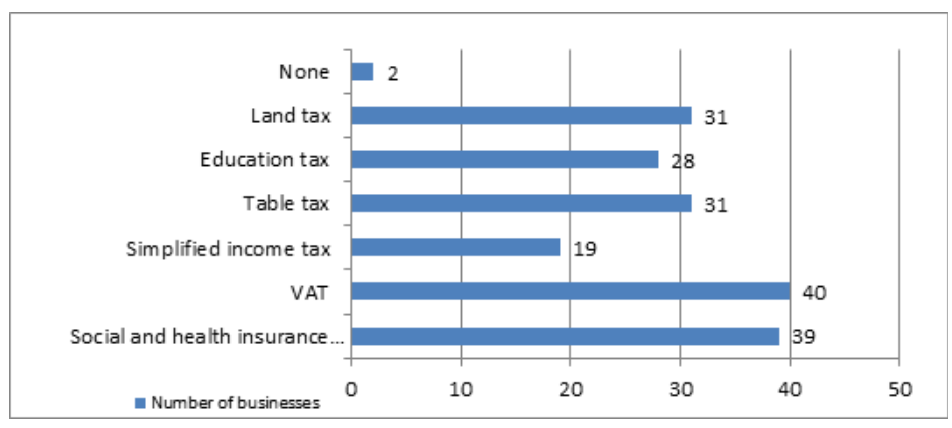

Figure 2. Business with annual turnover 5-8 million- Medium business. Which of the taxes and duties do you know?

Table 3. The Total Number of Businesses to which the Questionnaires were Distributed

\begin{tabular}{lc}
\hline Annual turnover & Bussinesses \\
\hline $5-8$ million & 45 \\
$0-5$ million & 296 \\
Unspecified & 7 \\
Total & 348 \\
\hline
\end{tabular}




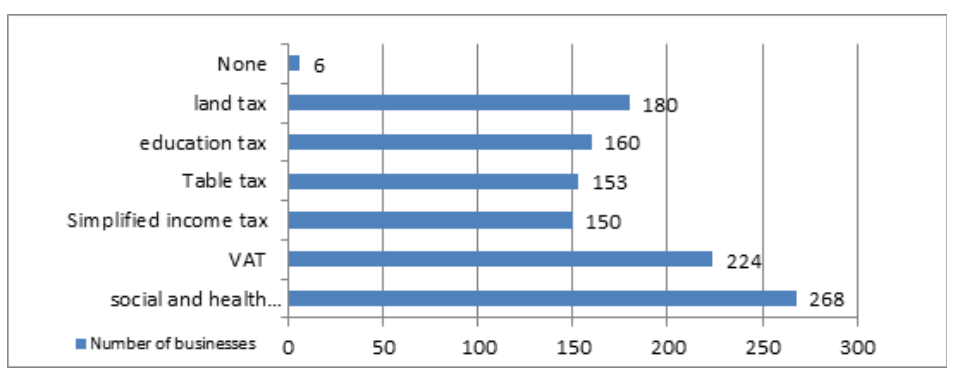

Figure 3. Businesses with annual turnover 0-5 million- Small business. Which of the taxes and duties do you know?

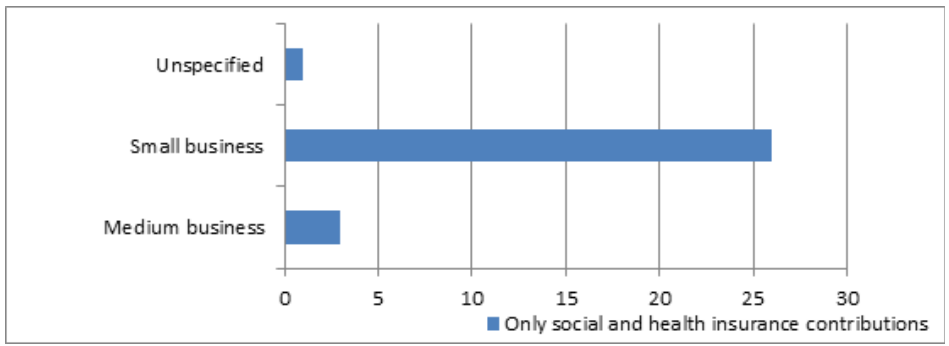

Figure 4. Businesses that know only social and health insurance contributions. 
Table 4. Do You Give Tax Coupon to Customers?

\begin{tabular}{lcc}
\hline Answers & $\begin{array}{c}\text { Do you give customers tax coupon at } \\
\text { any sale? }\end{array}$ & In \% \\
\hline Yes & 262 & $78 \%$ \\
No & 75 & $22 \%$ \\
Total & 337 & $100 \%$ \\
\hline
\end{tabular}

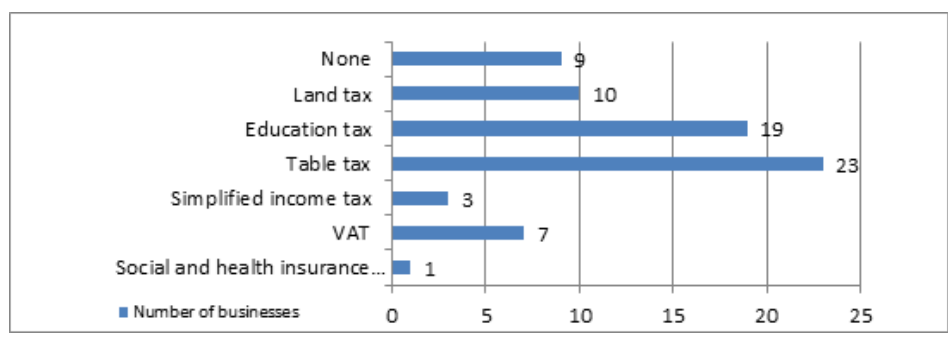

Figure 5. Medium businesses. Which of these obligations do you find excessive?

sent only a tax or a combination of them. Responses differ and the businesses are separated as small and medium as represented in Figure 2 and 3.

One of the dimensions of tax reform in 2015 was the declaration of all employees and the declaration and payment of social and health insurance contributions.

The answers indicate that all respondents were aware of the duty of declaration and payment of social and health insurance contributions, even though there were businesses that were only aware of these duties and not the others. $7 \%$ of medium businesses and $8.8 \%$ of small businesses know only social and health insurance contributions. In the analysis of the answers are taken into account only businesses that have completed the questionnaires.
There are only 13 medium businesses that are $29 \%$ and 94 small businesses that are $31.7 \%$ of businesses that have completed the questionnaires that know all obligations such as social and health insurance contributions, VAT and local taxes like simplified income tax, tax for table, education tax, and property tax. From the questionnaires it can be concluded that businesses know more about VAT and the social and social insurance contributions. So the problem of not paying these two liabilities correctly is not non-recognition. One possible explanation is the attitude of taxpayers towards taxes and distrust of the government.

To understand the willingness of tax compliance of these businesses, the following question was asked: which of these obligations do you look excessive? Business answers are summarized in the Figures 5 and 6. 


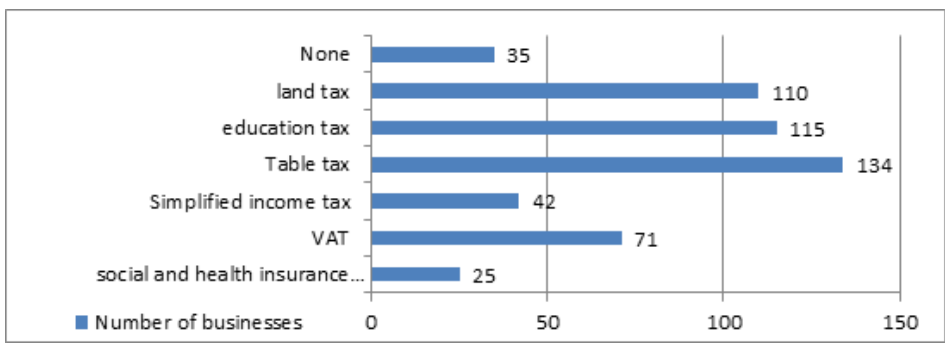

Figure 6. Small businesses. Which of these obligations do you find excessive?

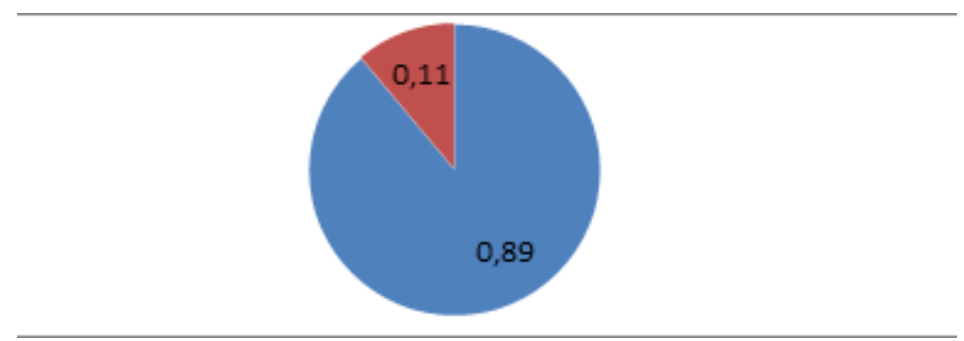

Figure 7. Medium businesses. Do you give customers tax coupon at any sale? 


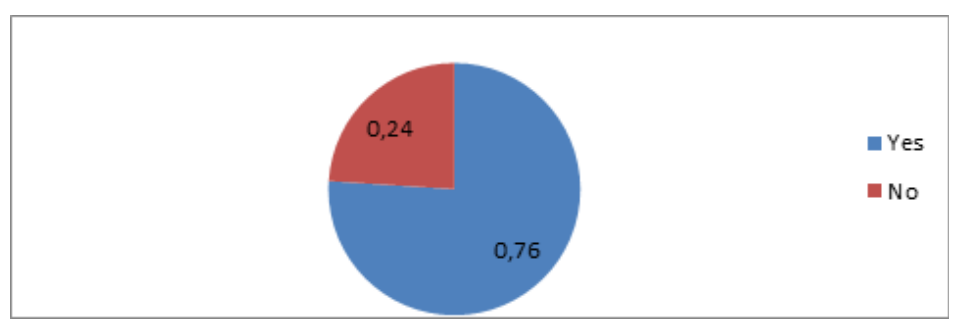

Figure 8. Small businesses. Do you give customers tax coupon at any sale?

Local taxes are generally considered to be excessive; they consider excessive taxes, in particular Table tax and Education tax.

Apparently for social and health insurance contributions, awareness is high. Businesses have understood the importance of paying contributions of employees and tax authorities need to find ways to force businesses to declare employee salaries correctly. Another finding is the fact that medium businesses are more aware of the obligation to pay taxes.

The questionnaire has questions about implementation of tax procedures. There are two questions for this, the first one for tax coupon and the second one for tax receipt. Giving a tax coupon at each sale is a very important obligation for businesses and the questions in the questionnaire are to understand their attitude about tax compliance. Tax coupon is issued by all taxable retailers, value added tax subjects and all taxable taxpayers of the simplified income tax. If a business for various reasons cannot give a tax coupon it has to give tax receipt. Tax coupon and tax receipt cannot serve as justification documents for deductible business expenses for the buyer.
Tax coupons are important for determining the business turnover and consequently also in categorizing businesses small, medium or big businesses. Determining the type of business is important for determination of taxes and duties a business will have to pay. So, if the business doesn't provide tax coupon this will result in incorrect business categorization and consequently tax evasion. A strong reason for giving the tax coupon is the business fairness towards the customers because businesses have an obligation to give buyers the coupon to validate purchases. Issuing a coupon means a legal receipt which confirms a purchase and related price. The Table 4 gives the number and percentage of small and medium businesses that give or don't give tax coupon to customers. There are $78 \%$ of them that give the tax coupon and $22 \%$ that don't give it. For this question only 337 businesses answered.

As indicated by their responses, most of them give tax coupon during sales. The \% that doesn't give is relatively high, especially considering the tax reform implemented. For being more precise or understanding who don't give tax coupon the answers of small businesses are separated from answers of medium businesses. This is shown in the Figure 7 and Figure 8. 


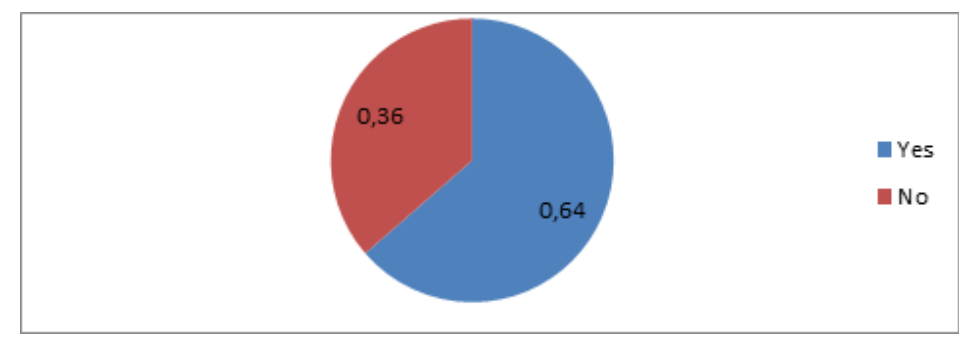

Figure 9. According to medium business, the \% of customers that ask for Tax Coupons.

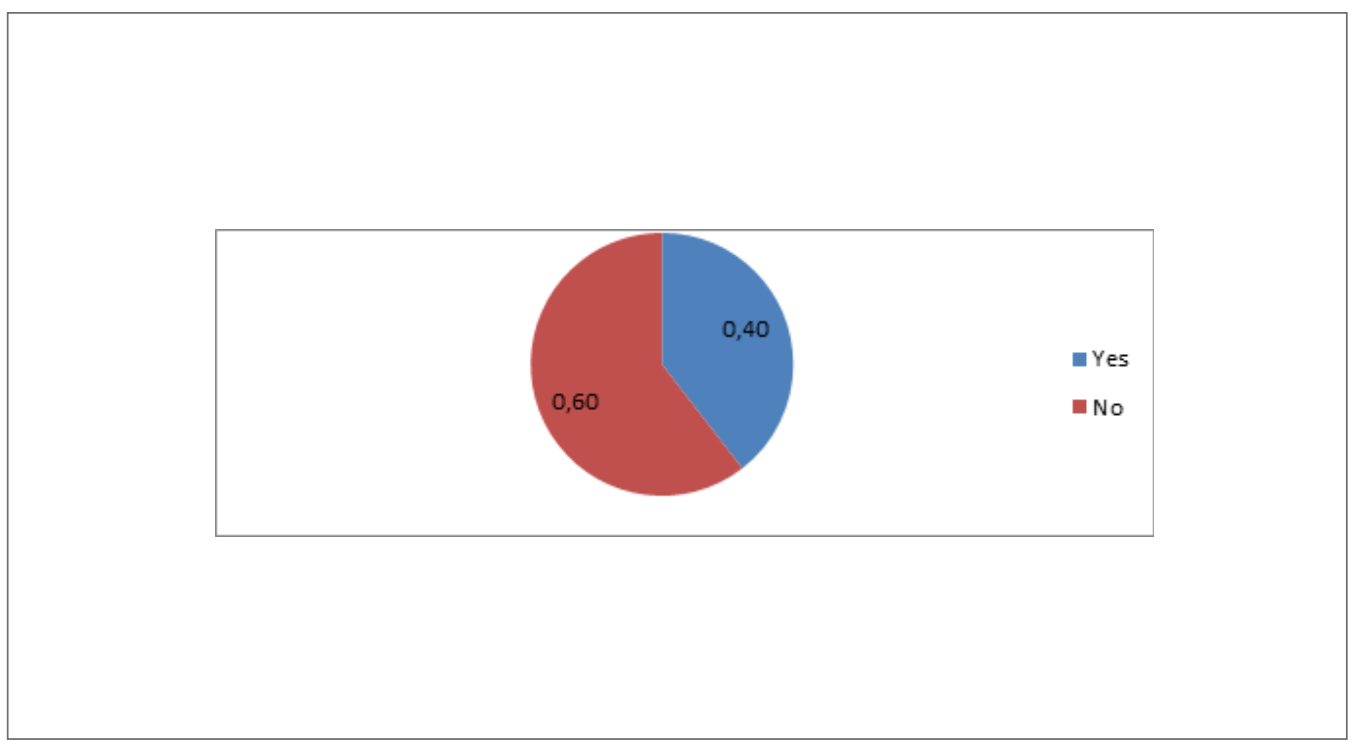

Figure 10. According to small business, the \% of customers that ask for Tax Coupons. 


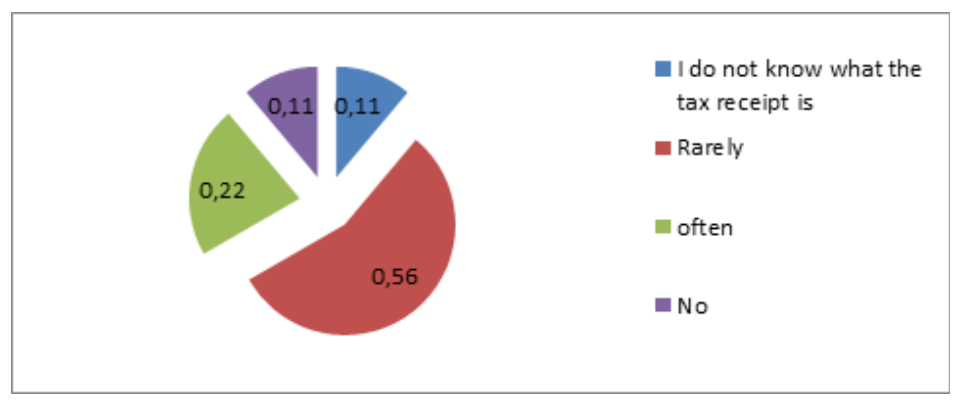

Figure 11. The \% of medium business that have used the tax receipt.

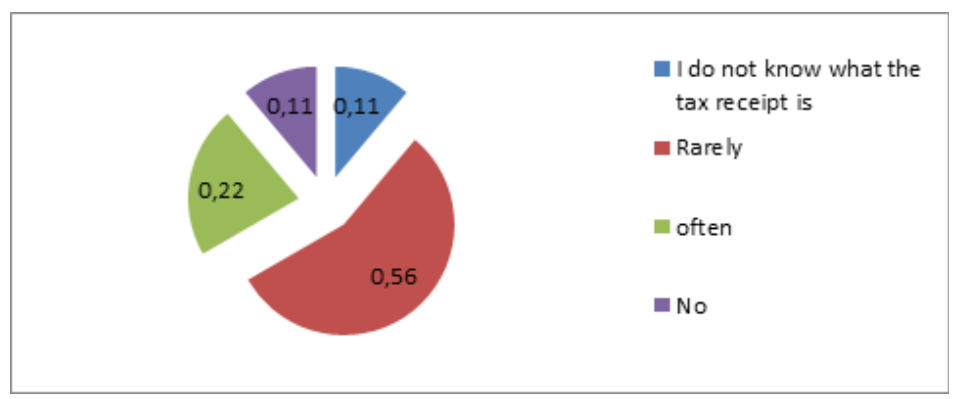

Figure 12. The \% of small business that have used the tax receipt. 
Table 5. Have You Ever Used a Tax Receipt?

\begin{tabular}{lcc}
\hline Answers & Have you ever used a tax receipt? & In \% \\
\hline I do not know the tax receipt & 50 & $15 \%$ \\
Rarely & 155 & $46 \%$ \\
often & 45 & $13 \%$ \\
No & 89 & $26 \%$ \\
Total & 339 & $100 \%$ \\
\hline
\end{tabular}

The responses indicate that there are more small businesses $24 \%$ of them that don't give the tax coupon comparing to medium businesses with $11 \%$ of them.

According to the tax procedures, if a business doesn't issue the tax coupon, the customer will be also fined from tax authority (not only the business). To understand customer's attitudes, businesses were asked if customers were looking for the tax coupon.

The answers show that not all customers require the tax coupon. In the case of medium businesses there are $64 \%$ of them that answer that customers ask tax coupon while in the case of small businesses $60 \%$ of answers indicate that the majority of customers do not ask for a tax coupon. Only $40 \%$ of small businesses answered positively this question. This indicates the low level of knowing the legislation by individuals or the simple fact that they are used not to take the coupon. Obviously, if customers are given a coupon they have no reason to ask.

The tax coupon is a duty to be given to customers in every sale, but if a business cannot give the tax coupon then it has to give the tax receipt. This question has been added to understand the knowledge of tax procedures. In the Table 5 are shown the total responses. The Figure 11 and 12 reflects the same answers but separately for small and medium businesses.

From the answers it is very interesting that 50 businesses do not know the tax receipt at all, like is showing in the table 5. But businesses probably didn't use it because they didn't need it.

\section{Conclusions and Recommendations}

The objective of the tax reform of 2015 in Albania was tax compliance. One of the main goals was the declaration of all employees and the declaration and payment of taxes and social and health insurance contributions. From the survey of SMEs in Tirana this paper concluded that there are still problems with tax compliance. The objective of the questionnaires was to understand whether firms know taxes and tax procedures. Non-recognition of taxes and duties will cause tax non-compliance. From the answers it is understood that businesses know the duties and the importance of social and health insurance contributions and VAT, there are even businesses that know only social and health insurance contributions, so the fact that businesses do not comply with these duties are businesses attitudes versus taxes and maybe distrust in tax administration. SMEs do not follow and respect tax procedures.

There is a low \% age of SMEs that know all duties. There are only $29 \%$ of medium businesses and $31.7 \%$ of small businesses who know all taxes and duties such as VAT, social insurance contributions and local taxes such as simplified income tax, table tax, education tax, and property tax.

In general, taxes are considered excessive by a number of businesses. Thus, there are 157 businesses that consider the table tax excess or a burden, specifically 51 $\%$ of medium businesses and $45 \%$ of small businesses. There are 134 businesses in total considering excess the education tax, which belong specifically $42 \%$ of medium businesses and $39 \%$ of small businesses. Meanwhile, 21 businesses consider all local taxes to be excessive. This indicates that tax agents should organize awareness meetings with businesses, especially with small businesses. Tax authorities must reassess taxes aiming their removal or review their levels because if taxpayers think that the tax burden is not fair this will negatively affect their attitude towards paying taxes as is concluded from Bărbuță-Mişu (2011). 
The problem that businesses don't provide the tax coupon to the customers continues. Thus, only $89 \%$ of medium business and $76 \%$ of small business gives tax coupon at any sale to the customers. To conclude whether customers are interested in tax compliance, businesses were asked if customers were looking for the coupon. While in the majority of medium businesses customers ask for the coupon, in $60 \%$ of the small businesses customers do not ask for it. In any case, tax authorities should pay more attention to small businesses. Almost the same conclusions have been reached by Aristovnik and Obadić (2015) which suggest the reduction of bureaucracies to grow businesses. In the same research is indicated that medium businesses are more aware of the need to pay their duties and know more taxes and procedures.

From the survey, it seems that tax authorities have a lot of work to do in raising awareness of businesses first in recognizing their taxes and duties and secondly in the correctness of their payment. From the questionnaire data, there are more small businesses that do not know taxes and tax procedures so small businesses are more tax noncompliance comparing with medium businesses. Tax authorities need to focus more on small businesses and their approach to taxation. This conclusion is in line with the conclusion of Ropret et al. (2018) that new small businesses lack the knowledge of regulatory requirements and removing administrative barriers will have a positive direct impact on the business environment. This conclusion is supported also from Ravšelj and Aristovnik (2018). They emphasized that regulatory authorities should consider the characteristics of small businesses and how they deal with administrative barriers when preparing and developing the legislation. According to Nyamwanza et al. (2014) most SMEs were found not to comply with income tax and PAYE because they don't believe in the tax system. Due to corruption in Albania, individuals do not trust the authorities and this can be a reason of noncompliance.

Tax authorities should conduct ongoing informative meetings with businesses and especially with small businesses. Tax authorities need to understand the tax and administrative burdens that burden and impede the progress of SMEs. Tax authorities need to get the opinion of the SMEs on taxes and take them into consideration. There is a need for information campaigns also for individuals, to be responsible customers.
This study has several limitations. The study is focused in Tirana, and the questionnaires were distributed only in Tirana businesses. In this study, not all the businesses reported annual turnover and not all the businesses answered all questions. Businesses were asked about the key local taxes and duties and procedures that were at the center of the reform and not for all taxes and duties.

Currently is discussing a new tax reform that aims to reduce informality through technology and a possible future study will be the study the SMEs tax compliance after new reform. Also for future research this study can be expanded with the inclusion of big businesses.

\section{References}

Abotsi K. A.,DakeY. G.\&Agyepong A. R. (2014). Factors influencing risk management decision of small and medium scale enterprises in Ghana. Contemporary Economics, 8(4), 397-414. https:// doi.org/10.5709/ce.1897-9254.153

Agu U. S., Okwo M. I., Ugwunta D. O \& Idike A. (2015). Fiscal policy and economic growth in Nigeria emphasis on various components of public expenditure. SAGE OPEN, 5(4), 1-12. https://doi. org/10.1177/2158244015610171

Alm J., Mcclelland G. \& Schulze W. (1992) Why do people pay taxes?Journal of Public Economics 48, 2138. https://doi.org/10.1016/00472727(92)90040M

Aristovnik, A. \&Obadić, A.(2015). The impact and efficiency of public administration excellence on fostering SMEs in EU countries. Amfiteatru Economic, 17(39), 761-774. http://hdl.handle. net/10419/168946

Atawodi W. O. \& Ojeka A. S. (2012). Factors that affect tax compliance among small and medium enterprises (SMEs) in North Central Nigeria. International Journal of Business and Management, 7(12), 86-96. https://doi.org/10.5539/ijbm.v7n12p87

Bărbuță-Mişu N. (2011). A review of factors for tax compliance. Annals of Dunărea de Jos University. Fascicle I: Economics and Applied Informatics, 1, 68-76. https://core.ac.uk/download/ pdf/26692348.pdf

Bohanon C., Horowitz B. J. \& McClure J. (2014). Saying too little, too late: Public finance textbooks and the excess burdens of taxation. Econ Journal Watch, 11(3), 277-296. https://econpapers.repec. org/RePEc:ejw:journl:v:11:y:2014:i:3:p:277-296

Doran M. (2009). Tax penalties and tax compliance. 
Georgetown University Law Center, 46, 111-161. https://scholarship.law.georgetown.edu/facpub/915/

Frey. S. B. (2011). Punishment - and beyond. Contemporary Economics, 5(2), 90-99. https://doi. org/10.5709/ce.1897-9254.15

General Tax Directorate. (2015). Annual report 2015. https://www.tatime.gov.al/shkarko.php?id=110

Institute of Statistics (INSTAT). (2014). Albanian population projections 2011-2031. http://www. instat.gov.al/media/3075/projeksionet_e_popullsis_2011-2031.pdf

Institute of Statistics (INSTAT). (2018a). Statistics for small and medium enterprises, 2016. http:// www.instat.gov.al/en/themes/industry-trade-andservices/structural-business-statistics/publication/2018/statistics-on-small-and-medium-enterprises-2016/

Institute of Statistics (INSTAT). (2018b) Quarterly labor force survey, quarter II, 2018.http://www.instat.gov.al/media/4719/atfp-t2-2018_.pdf

Oliver, L. (2015). Importance of accurate financial statements for a business. Invensis Global Outsourcing Services. https://www.invensis.net/blog/ finance-and-accounting/importance-accuratefinancial-statements-business/

Ministry of Finance and Economy. (2018). Fiscal indicators regarding consolidated budget of 2018.http:// financa.gov.al/wp-content/uploads/2018/07/treguesit_fiskal_05 2018_dt.25.06.2018_(publikimi). pdf

Ministry of Finance and Economy. (2019). Status report on local public finances - 2018. Local Finance Portal. http://financatvendore.al/pub/raporte

Nyamwanza T., Mavhiki S., Mapetere D. \& Nyamwanza L. (2014). An analysis of SMEs' attitudes and practices toward tax compliance in Zimbabwe. SAGE OPEN, 4(3), 1-6. https://doi. org/10.1177/2158244014542776

Ravšelj, D., \&Aristovnik, A. (2018). Administrative barriers for SMEs in the field of tax compliance and financial and accounting reporting: Evidence from Slovenia. Problemy Zarzadzania, 1(73), 7590. https://doi.org/10.7172/1644-9584.73.5

Ropret, M., Aristovnik, A., \& Ravšelj, D. (2018). The perception of administrative barriers and their implications for SMEs' performance: Evidence from Slovenia. Zagreb International Review of Economics \& Business, 21(SCI), 55-68. https://doi. org/10.2478/zireb-2018-0024

Strader J.,\&Fogliasso E.Ch. (1989). An investigation of some factors affecting taxpayer non-compliance. Accounting and Business Research, 20(77), 39-46. https://doi.org/10.1080/00014788.1989.9729393

The Organisation for Economic Co-operation and Development (OECD). (2004). Compliance risk management: Managing and improving tax compliance. Centre for Tax Policy and Administration. http:// www.oecd.org/tax/administration/ 33818656.pdf

Umar M. A., Derashid C. \& Ibrahim I. (2017). What is wrong with the fiscal social contract of taxation in developing countries? A dialogue with self-employed business owners in Nigeria, SAGE OPEN,7(4), 1-11. https://doi. org/10.1177/2158244017745114

Virglerová, Z., Dobeš, K., \& Vojtovič, S. (2016). The perception of the state's influence on its business environment in the SMEs from Czech Republic. Administratiesi Management Public, (26), 78-96. ISSN 1583-9583. http://www.ramp.ase.ro/en/_ data/files/articole/2016/26-05.pdf.

Waegenaere, A., Sansing, R. \& Wielhouwer, J. L. (2015). Financial accounting effects of tax aggressiveness: Contracting and measurement. Contemporary Accounting Research, 32(1),223-242. https://doi. org/10.1111/1911-3846.12068

World Bank Group. (2018a). Doing business 2018. Reforming to create jobs. https://www.doingbusiness. org/content/dam/doingBusiness/media/AnnualReports/English/DB2018-Full-Report.pdf.

World Bank Group. (2018b). Paying taxes 2018. https://www.pwc.com/gx/en/paying-taxes/pdf/ pwc_paying_taxes_2018_full_report.pdf. 